\title{
Pengaruh Gaya Kepemimpinan Situasional, Motivasi dan Pelatihan Pada Kinerja Karyawan di Koperasi Pasar Srinadi Klungkung
}

\author{
Ni Luh Komang Sri Noviani' \\ Ni Luh Sari Widhiyani²
}

\author{
${ }^{1}$ Fakultas Ekonomi dan Bisnis Universitas Udayana (Unud), Bali, Indonesia \\ email: srinoviani18@yahoo.com/Telp: 083114594379 \\ ${ }^{2}$ Fakultas Ekonomi dan Bisnis Universitas Udayana (Unud), Bali, Indonesia
}

\begin{abstract}
ABSTRAK
Tujuan penelitian ini adalah untuk memperoleh bukti empiris pengaruh gaya kepemimpinan situasional, motivasi dan pelatihan pada kinerja karyawan di Koperasi Pasar Srinadi Klungkung. Penelitian ini dilakukan pada seluruh karyawan yang berjumlah 350 dan tersebar di sembilan unit usaha Koppas Srinadi Klungkung. Jumlah sampel yang diambil sebanyak 78 karyawan, dengan metode probability sampling, tehnik proportional random sampling. Pengumpulan data dilakukan melalui survei dan kuesioner. Teknik analisis yang digunakan adalah regresi linear berganda. Berdasarkan hasil analisis dan pengujian hipotesis gaya kepemimpinan situasional berpengaruh positif pada kinerja karyawan, motivasi berpengaruh positif pada kinerja karyawan dan pelatihan berpengaruh positif pada kinerja karyawan. Pengaruh positif dari variabel gaya kepemimpinan situasional, motivasi dan pelatihan terhadap kinerja karyawan, telah membuktikan teori yang digunakan yaitu teori perilaku organisasi.
\end{abstract}

Kata kunci: Gaya kepemimpinan situasional, motivasi, pelatihan, kinerja karyawan

\begin{abstract}
The purpose of this study was to obtain empirical evidence of the influence of situational leadership style, motivation and training on employee performance in the Srinadi Klungkung Cooperative Market. This study was conducted on all 350 employees and spread across nine Koppas Srinadi Klungkung business units. The number of samples taken was 78 employees, with probability sampling method, proportional random sampling technique. Data collection was carried out through surveys and questionnaires. The analysis technique used is multiple linear regression. Based on the results of the analysis and testing of hypotheses situational leadership style has a positive effect on employee performance, motivation has a positive effect on employee performance and training has a positive effect on employee performance. The positive influence of the variable situational leadership style, motivation and training on employee performance, has proven the theory used is the organizational behavior theory.
\end{abstract}

Keywords: Situational leadership style, motivation, training, employee performance.

\section{PENDAHULUAN}

Sumber Daya Manusia (SDM) memiliki peranan yang penting bagi perusahaan.

SDM membantu menunjang tercapainya tujuan perusahaan melalui

kemamampuan yang ada dalm setiap diri individu (Hidayati dkk.,2015). Salah

satu bagian dari sumber daya manusia dalam perusahaan yang sangat menentukan 
Ni Luh Komang Sri Noviani dan Ni Luh Sari Widhiyani. Pengaruh...

pencapaian tujuan perusahaan adalah karyawan. Karyawan adalah salah salah satu bagian penting utuk kelangsungan hidup organisasi. Kenyamanan yang dirasakan oleh karyawan akan sangan membantu dalam meningkatkan kinerja karyawan. Hal ini tentunya akan berimbas pada keberhasilan pencapain tujuam perusahaan.

Kinerja karyawan didefinisikan sebagai gambaran hasil pencapaian dari pelaksanaan kegiatan untuk mewujudkan target yang telah ditetapkan oleh perusahaan melalui sebuah perencanaan strategi organisasi (Karma dkk., 2016). Peningkatan kinerja karyawan tidak akan terlepas dari sosok pemimpin sebagai pihak yang bertanggung jawab dalam organisasi. Menurut Untari dkk., (2015) apabila pemimpin mampu menjalankan kepemimpinan yang tepat maka tujuan organisasi untuk meningkatkan kinerja karyawan akan lebih mudah tercapai. Pendapat ini didukung oleh Sudarmanto (2009:133) yang menegaskan bahwa bahwa kepemimpinan dijadikan sebagai tolak ukur sejauh mana kompetensi yang dimiliki oleh pemimpin untuk menunjang peningkatan kinerja karyawan. Seorang pemimpin yang mampu mengayomi bawahan dengan baik, cenderung akan memotivasi karyawan untuk meningkatkan kualitas kerja yang dimiliki.

Gaya kepemimpinan didefinisikan sebagai gambaran bagaimana seorang pemimpin mampu mempengaruhi karyawan dan membuat karyawan bertindak sesuai dengan arahan yang pemimpin berikan tanpa ada paksaan dan rasa takut dalam diri karyawan. merupakan suatu gambaran perilaku sesorang dalam mempengaruhi orang lain agar keinginan orang tersebut diikuti oleh orang lain, tanpa ada paksaan atau tekanan (Amalia dkk.,2016). Paul Hersey dan Ken 
ISSN: 2302-8556

E-Jurnal Akuntansi Universitas Udayana

Vol.25.3.Desember (2018): 2212- 2241

Blanchard mencetuskan sebuah model kepemimpinan yang disebut dengan Teori Kepemimpinan Situasional.

Kepemipinan Situasional merupakan seuah teori yang menekankan pada kondisi bawahan atau pengikut. Gaya kepemimpinan ini menjelaskan bagaimana seorang pemimpin mampu melakukan penyesuaian diri dengan kematangan bawahan dan lingkungan kerja perusahaan. Gaya kepemimpinan situasional sangatlah fleksibel, sehingga sangat cocok untuk mewakili kondisi persaingan global yang terus saja mengalami perubahan dengan sangat pesat. Perusahaan dituntut untuk lebih adaptif terhadap kemajuan dan perubahan, sehingga keberlangsungan hidup perusahaan juga akan terjamin. Upaya yang dapat dilakukan untuk menghadapi kondisi tersebut tiada lain dengan menerapkan gaya kepemimpinan situasional dalam memimpin sebuah organisasi atau perusahaan (Samsuri dkk.,2014). Beberapa penelitian terdahulu diantaranya Hidayati dkk., (2015) dan Ghazzawi et al., (2017) memperoleh hasil penelitian yang menyatakan bahwa gaya kepemimpinan situasional berpengaruh positif terhadap kinerja karyawan. Ini menunjukkan bahwa gaya kepemimpinan situasional akan sangat membantu dalam meningkatkan kinerja karyawan.

Kinerja karyawan tidak hanya dipengarughi oleh gaya kepemimpinan situasioanl. Selain faktor gaya kepemimpinan situasional, motivasi juga sangat dibutuhkan untuk meningkatkan semangat kerja karyawan. Motivasi adalah bentuk dorongan baik yang berasal dari dalam diri individu maupun dorongan dari dari luar yang membuat seseorang mau bertindak dan melaksanakan tugas dengan baik. Karyawan yang kurang memiliki motivasi cenderung memiliki semangat 
kerja yang rendah. Hal ini tentunya akan merugikan perusahaan, karena kinerja yang rendah akan berdampak pada terhambatnya pencapaian tujuan perusahaan, dengan demikian perusahaan dituntut untuk mampu meningkatkan motivasi karyawan (Zameer et al.,2014). Kusuma dkk., (2015) menjelaskan bahwa ketika karyawan tidak memiliki motivasi, karyawan tidak akan bekerja dengan baik dan tujuan perusahaan akan sulit tercapai. Riani dkk., (2017), Husna dkk., (2016) dan Triayong dkk., (2013) memperoleh hasil analisis yang menyatakan bahwa motivasi berpengaruh positif pada kinerja karyawan.

Motivasi tidak hanya terbatas pada pemberian pengarahan secara langsung melalui tutur kata melainkan bisa disalurkan melalui tindakan nyata seorang pemimpin. Pemberian motivasi kepada karyawan seringkali dilakukan pada saat pelatihan. Pelatihan menjadi salah satu upaya yang dilakukan oleh pemimpin untuk meningkatkan kinerja karyawan. Pelatihan sering kali dilakukan oleh perusahaan sebagai bentuk penyeragawan wawasan dan peningkatan kemampuan teknis bagi karyawan. Pelatihan tidak hanya dilakukan bagi karyawan yang berstatus sebagai pegawai baru, melaikan juga bagi karyawan yang sudah lama bekerja. Hal ini dilakukan untuk membantu meningkatkan kualitas kerja dari karyawan, sehingga kinerja karyawan juga akan semakin membaik. Afroz (2018) menyatakan bahwa pelatihan merupakan serangkaian kegiatan yang bertujuan memberikan atau menambah kemampuan yang dibutuhkan seseorang dalam menyelesaikan pekerjaannya. Kusuma dkk., (2015) dan Riani dkk., (2017) melakukan telah melakukan penelitian megenai pengaruh pelatihan terhadap kinerja, dimana hasil penelitian tersebut menunjukkan bahwa pelatihan memiliki pengaruh positif terhadap kinerja karyawan.

Koperasi sebagai salah satu bentuk organisasi yang mewadahi kebutuhan anggota khususnya dan masyarakat umumnya tidak akan terlepas dari sosok pemimpin. AAGN 
ISSN: 2302-8556

E-Jurnal Akuntansi Universitas Udayana

Vol.25.3.Desember (2018): 2212- 2241

Puspayoga selaku Menteri Koperasi dan UKM sangat mengapresiasi keberadaan koperasi sebagai salah satu penunjang perekonomian di Indonesai. Bentuk kepedulian tersebut ditunjukkan dengan pemberian penghargaan bagi bagi 13 koperasi berdasarkan pengelola aset terbesar, volume usaha terbesar, CSR terbaik dan IT terbaik (kontan.co.id, 2018). Salah satu koperasi yang memperoleh penghargaan tersebut adalah Koperasi Pasar Srinadi Klungkung sebagai koperasi konsumen dengan aset terbesar (industry.co.id, 2017).

Menurut data dari Dinas Koperasi dan UMKM Provinsi Bali Tahun 2018 bahwa Koperasi Pasar Srinasi Klungkung masih menduki posisi sebagai koperasi terbaik di Bali (depkop.go.id, 2018). Keberadaan Koperasi Pasar Srinadi Klungkung sebagai koperasi terbaik di Bali dan salah satu koperasi terbaik di Indonesia tidak terlepas dari sosok pemimpin yang mengelola koperasi tersebut. Menurut Putera (2018:23) terjadi peningkatan yang sangat drastis semenjak terjadi penggantian manajer. Penghargaan demi penghargaan mulai dari tingkat kabupaten, provinsi hingga nasional disandang oleh Koppas Srinadi di bawah tonggak kepemimpinan Bapak I Nyoman Suwirta. Tipe kepemimpinan yang diterapkan oleh manajer baru Koppas Srinadi sangat mengarah pada kepemimpinan situasional. Hal ini dapat dilihat dari kemampuan manajer dalam mempengaruhi karyawan dan pengurus koperasi dengan berorientasi pada tugas dan hubungan.

Putera (2018:23) menegaskan bahwa Bapak Nyoman Suwirta adalah sosok pemimpin yang merakyat dan selalu menjadi motivator tidak hanya bagi anggota maupun karyawan, bahkan bagi koperasi-koperasi yang ada di luar daerah Bali. Sosok motivator inilah yang membuat karyawan dan pengurus senantiasa bekerja secara maksimal. Pemberian motivasi biasanya dilakukan pada saat kegiatan 
pelatihan yang diselenggarakan bagi karyawan setiap tahun dan tidak jarang dilakukan ketika kegiatan pengawasan berlangsung. Hal inilah yang membuat Koppas Srinadi menjadi koperasi yang besar hingga memiliki 9 unit usaha dan berhasil menduduki posisi sebagai koperasi terbaik di Bali bahkan masuk kategori 13 koperasi terbaik di Indonesia hingga tahun 2018 (nusabali.com, 2018).

Fenomena tersebut menjadi landasan bagi peneliti untuk membuat sebuah penelitian mengenai pengaruh gaya kepemimpinan situasional, motivasi dan pelatihan pada kinerja karyawan di Koperasi Pasar Srinadi Klungkung. Penelitian ini bertujuan untuk membuktikan secara empiris pengaruh gaya kepemimpinan situasional motivasi dan pelatihan pada kinerja karyawan. Secara teoritis manfaat penelitian ini adalah dapat dijadikan bahan kajian dan bahan perbandingan pada penelitian yang relevan, dapat membuktikan teori perilaku organisasi serta dapat menunjang pengembangan teori-teori pendukung dari teori perilaku organisasi meliputi konsep manajemen sumber daya manusia, gaya kepemimpinan situasional, motivasi dan pelatihan dalam upaya peningkatan kinerja karyawan. Secara praktis penelitian ini dapat memberikan referensi tambahan informasi kepada koperasi untuk meningkatkan pemahaman tentang pentingnya gaya kepemimpinan situasional, motivasi dan pelatihan dalam meningkatkan kinerja karyawan, sehingga tujuan koperasi akan semakin mudah tercapai.

Perilaku organisasi adalah realisasi dari pengetahuan mengenai cara seseorang dalam bertindak ketika menjalankan kegiatan di sebuah organisasi (Mulyadi, 2015:11). Subekhi dan Jauhar (2013:24) menjelaskan bahwa perilaku organisasi menjadi bidang khusus dari ilmu pengetahuan yang mengandung tiga 
hal penting untuk menentukan perilaku individu ketika menjalankan aktifitas di dalam organisasi. Tiga hal penting tersebut meliputi: individu, kelompok, dan struktur beserta penerapannya, ketiga hal inilah yang nantinya akan berperan dalam mencapai kinerja organisasi secara efektif.

Thoha (2007:34) menjelaskan perilaku organisasi adalah ilmu yang didalamnya membahas segala aspek tingkah laku manusia ketika berinteraksi dalam dalam suatu organisasi. Melihat definisi dari perilaku organisasi yang dikemukakan oleh Mulyadi, Thoha serta Subekhi dan Jauhar, maka teori perilaku organisasi ini sangat tepat digunakan sebagai dasar pelaksanaan aktivitas di dalam organisasi baik dalam lingkup besar maupun lingkup yang lebih kecil seperti koperasi. Mengingat aktivitas di dalam organisasi tidak akan terlepas dari sosok seorang pemimpin dan karyawan, maka teori perilaku organisasi ini dapat dijadikan sebagai pedoman dalam menjalin interaksi yang baik antara manajer dengan karyawan.

Teori perilaku organisasi akan tercermin dari bagaimana sikap seorang manajer koperasi dalam menggerakan bawahannya. Seorang manajer yang baik harus mampu memotivasi dan peka terhadap kondisi karyawan (Purnamasari, 2016). Sikap manajer yang demikian dapat ditemukan pada gaya kepemimpinan situasional. Gaya kepemimpinan situasional menekankan pada kemampuan pemimpin dalam menyesuaikan diri dengan kematangan bawahan.

Sosok pemimpin yang mau memperhatikan kondisi bawahan, akan membuat karyawan termotivasi untuk bekerja secara maksimal. Gambaran dari gaya kepemimpinan situaional ini juga dapat dilihat dari upaya pemimpin 
Ni Luh Komang Sri Noviani dan Ni Luh Sari Widhiyani. Pengaruh...

mengadakan pelatihan demi peningkatan kualitas kerja karyawannya. Hal ini sejalan dengan teori perilaku organisasi yang menjabarkan cara mengelola SDM melalui kegiatan manajemen kerja (managing work) dan manajemen orang (managing people) agar dapat bekerja secara efektif. Manajemen kerja berhubungan dengan fungsi perencanaan, pengorganisasian, dan pengendalian, sedangkan manajemen orang berhubungan dengan fungsi komunikasi, kepemimpinan, motivasi dan keterampilan (Subekhi \& Jauhar, 2013:24).

Kepemimpinan atau leadership berasal dari dari akar kata to lead yang artinya memimpin. Kepemimpinan didefinisikan sebagai aktivitas untuk mengarahkan orang lain agar bersedia bertindak sesuai arahan yang diberikan dalam mencapai tujuan bersama (Duquesnoy, 2011). Menurut Cote, (2017) kepemimpinan adalah sebuah proses memberikan inspirasi kepada karyawan atau bawahan agar bersedia bekerja dengan sungguh-sungguh tanpa merasa ada tekanan atau paksaan. Bhargavi \& Yaeen (2016) mengatakan pemimpin yang baik adalah pemimpin yang mampu menerapkan gaya kepemimpinan situasional dengan memperhatikan adanya faktor-faktor organisasi, pemimpin, bawahan dan situasi penugasan.

Afshinpour., (2013) menjelasakn gaya kepemimpinan situasional merupakan gaya yang mengedepankan kondisi bawahan. Bhargavi \& Yaseen (2016) gaya kepemimpinan situasional adalah keahlian yang dimiliki oleh manajer untuk menganalisis isyarat-isyarat yang ditunjukkan oleh karyawan, sehingga pemimpin dapat mendiagnosa, kemudian mengadaptasi gaya kepemimpinan sesuai dengan kondisi tersebut. Kematangan bawahan menjadi tolok ukur bagi 
pemimpin dalam menetapkan gaya kepemimpinan yang cocok diterapkan. Ketika bawahan berada pada tahap awal memasuki lingkungan kerja dan belum mengetahui tugas maupun tanggung jawab, pemimpin akan lebih menekankan pada perilaku tugas, sedangkan ketika bawahan telah memahami tugas dan tanggung jawab nya masing-masing, maka pemimpin cenderung lebih menekankan pada perilaku hubungan. Menurut teori kepemimpinan situasional tidak ada cara terbaik bagi manajer atau pemimpin untuk mempengaruhi perilaku orang-orang. Pemimpin akan mampu menerapkan gaya kepemimpinan yang tepat, apabila pemimpin jeli dalam mengamati tingkat kematangn karyawan (Mohammed et al., 2014).

Hersey dan Blanchard dalam Iqbal et al, (2015) membuat 4 dimensi atau bentuk kepemimpinan dalam kepemimpinan situasional yang merupakan kombinasi dari perilaku tugas dan perilaku hubungan. Pertama telling, pada tahap ini karyawan masih dalam proses mengenal lingkungan organisasi, belum memahami tugas dan tanggung jawab yang harus diemban, maka orientasi tugas akan lebih tinggi daripada orientasi hubungan yang Bawahan harus lebih banyak diberi perintah dalam melaksanakan tugasnya dan diperkenalkan dengan aturanaturan dan prosedur organisasi. Kedua selling, pada tahap ini karyawan sudah mulai menetahui tugas yang harus dikerjakan, akan tetapi karyawan pada tahap ini masih belum berani memikul tanggung jawab tanpa ada bimbingan dari pemimpin, maka kepemimpinan orientasi tugas dan hubungan sama-sama tinggi. Ketiga participating, pada tahap ini karyawan cenderung memiliki motivasi yang tinggi dalam mengerjakan tugas, dan karyawan telah bersedia memikul penuh 
tanggung jawab secara utuh, maka ditahap ininorientasi hubungan harus lebih tinggi daripada ortintasi tugas. Keempat delegating, pada tahap ini bawahan sudah memiliki rasa percaya diri yang tinggi, pengalaman yang sudahh semakin luas, dan bahkan karyawan sudah mau memikul tanggung jawab lebih, sehingga kontrol dari pemimpin sudah semakin sedikit. Pada tahap ini pemimpin akan mnengurangi baik orintasi tugas maupun oriantasi hubungan (Iqbal et al., 2015).

Guven, (2013) menyatakan motivasi merupakan sebuah dorongan yang membuat seseorang memiliki keinginan untuk bertindak dan bekerja sama dengan orang lain, bekerja secara terintegrasi, dan efektif untuk memperoleh sebuah kepuasan. Motivasi juga diartikan sebagai daya penggerak yang bersal dari dalam dan luar diri karyawan agar dapat melaksanakan tugas sesuai dengan aturan yang ditetapkan oleh perusahaan untuk mewujudkan target perusahaan secara optimal. Motivasi kerja akan menjadi gambaran sejauh mana karyawan mampu menunjukkan kinerja sesuai dengan tugas dan tanggung jawab yang telah dibebankan oleh pemimpin dalam mewujudkan visi, misi dan sasaran perusahaan (Samsuri dkk., 2014)

Motivasi sangat membantu dalam upaya meningkatkan kinerja karyawan. Biasanya karyawan yang termotivasi akan bekerja keras untuk menunjukkan kinerja yang optimal dalam mengerjakan tugas-tugasnya, hal inilah yang mebuat prestasi kerja karyawan semakin membaik (Elqadri et al., 2015). Keberadaan motivasi tidak terlepas dari faktor-fakto yang mempengaruhi kinerja karyawan. Banyak faktor yang mempengaruhi motivasi, salah satunya adalah gaya kepemimpinan yang diterapkan pemimpin dan kondisi lingkungan kerja (Triayong 
dkk., 2013). Motivasi dapat dibedakan menjadi dua macam yaitu motivasi positif dan motivasi negatif. Motivasi positif bersifat jangka panjang dan motivasi negatif bersifat jangka pendek, dan penerapan harus adil serta konsisten.

Motivasi positif dapat meliputi pemberian penghargaan bagi karyawan yang memiliki prestasi kerja yang baik, penghargaan yang diberikan dapat berupa kenaikan jabatan, pemberian bonus tambahan maupun tiket berlibur, sedangkan motivasi negatif dapat perusahaan berikan bagi karywan yang yang bekerja dengan tidak sungguh-sungguh. Motivasi negatif yang dapat manajer berikan meliputi pemberian ancaman pemecatan, penurunan jabatan dan pemotongan gaji. Dua bentuk motivasi tersebut akan membuat karyawan berlomba-lomba dalam meningkatkan kinerja dan takut untuk bermalas-malasan ataupun lalai dalam menjalankan tugas dan tanggung jawab (Gardjito dkk., 2014).

Pelatihan adalah upaya memperbaiki kinerja karyawan melalui pemberian wawasan atau pengetahuan dan penerapannya secara langsung untuk mencapai tujuan perusahaan (Dewi, 2014). Pelatihan juga dapat diartikan sebagai proses meningkatkan atau memperluas pengetahuan dan keterampilan kerja karyawan agar dapat menghasilkan prestasi kerja yang optimal. Peningkatan intensitas pelatihan akan sangat membantu dalam meningkatkan kinerja karyawan (Ramya, 2016). Menurut Kusuma dkk., (2015) pelatihan memiliki manfaat untuk meningkatkan dan memperbaiki penguasaan berbagai keterampilan dan teknik pelaksanaan kerja tertentu secara terinci dan rutin. Turere (2013) menjelaskan bahwa pelatihan dijadikan sebagai sebuah proses bagi perusahaan untuk membantu karyawan dalam meningkatkan kualitas kerja, sehingga tujuan 
perusahaan akan lebih mudah tercapai. Pelatihan dapat diumpamakan sebagai investasi SDM (human investment) untuk meningkatkan kemampuan keterampilan kerja dan pengetahuan, dengan demikian kinerja karyawan akan semakin meningkat (Elnaga \& Imran, 2013).

Kinerja karyawan adalah wujud prestasi kerja yang ditunjukkan karyawan kepada perusahaan. Kinerja dapat dijadikan sebagai tolak ukur sejauh mana keberhasilan perusahaan dalam mencapai tujuan yang telah ditetapkan (Wanjala, 2014). Kinerja sering kali digunakan sebagai istilah untuk menyebut prestasi atau tingkat keberhasilan individu dan kelompok. Keberhasiln kerja akan ditunjukkan melalui kesuskesan perushaan mencapai tujuan atau targat (Ghazzawi et al., 2017). Karyawan dikatakan memiliki kinerja yang baik apabila mampu mengasilkan prestasi kerja yang baik. Prestasi kerja yang dimaksud tiada lain berupa kualitas, kuantitas dan waktu penyelesaian sesuai dengan standar kerja yang tekah dibuat oleh perusahaa (Duquesnoy, 2011).

UU No 25 Tahun 1992 menjelaskan bahwa, koperasi merupakan badan usaha yang beranggotakan orang-seorang atau badan hukum koperasi dengan melandaskan kegiatannya berdasarkan prinsip koperasi sekaligus sebagai gerakan ekonomi rakyat yang berdasar atas aasas kekeluargaan. Tujuan koperasi yaitu memajukan kesejahteraan anggota pada khususnya dan masyarakat pada umumnya serta ikut membangun tatanan perekonomian nasional dalam rangka mewujudkan masyarakat yang maju, adil dan makmur berdasarkan Pancasila dan Undang-Undang Dasar 1945. Koperasi juga merupakan urat nadi perekonomian Indonesia yang bertujuan untuk membantu masyarakat dengan ekonomi lemah 
dan mempunyai usaha yang potensial untuk dikembangkan. Hal ini juga telah diatur dalam Undang-Undang No. 25 pasal 4 mengenai fungsi dan peran koperasi.

Koperasi Pasar Srinadi Klungkung (Koppas Srinadi) adalah salah satu koperasi besar yang ada di Bali dan telah berbadan hukum nomor: 1089/BH/VIII pada tanggal 14 Desember 1985. Koppas Srinadi Klungkung resmi didirikan di Jl. Mahoni, Semarapura Kelod, Kabupaten Klungkung. Awalnya, koperasi ini hanya berfokus pada pengelolaan simpan pinjam, sehingga unit pertama yang dibangun adalah unit simpan pinjam. Seiring dengan kemajuan persaingan global yang semakin pesat dan kebutuhan masyarakat yang semakin beragam, maka Koppas Srinadi mulai membangun unit-unit usaha baru untuk memenuhi kebutuhan anggota khususnya dan masyarakat pada umumnya. Tidak heran jika koperasi ini mampu membangun delapan unit usaha baru mengingat jumlah anggotanya saat ini telah mecapai 15.000 orang. Koperasi ini juga merupakan koperasi berprestasi, banyak penghargaan yang telah Koppas Srinadi Klungkung peroleh mulai dari Koperasi Berprestasi Tingkat Nasional, Koperasi Award 2016, bahkan pengharagaan sebagai koperasi terbaik di Bali. Hal ini tidak diragukan lagi, terlihat dari dari beragamnya usaha yang dimiliki oleh Koperasi Pasar Srinadi yaitu unit swalayan mini, unit simpan pinjam, unit grosir, unit percetakan dan konveksi, unit swalayan bangunan, unit supermarket inti, unit wisata tirta, unit bengkel, dan unit radio (nusabali.com, 2018).

Gaya kepemimpinan situasional merupakan tipe kepemimpinan yang selalu berusaha mneyesuaikan diri dengan bawahan. Gaya kepemimpinan ini sangat sangat efektif diterapkan di dalam organisasi. Kemampuan pemimpin dalam 
membaca situasi karyawan akan sangat membantu meningkatkan kinerja dari karyawan. Riani dkk., (2017) melakukan penelitian terkait dengan pengaruh gaya kepemimpinan pada kinerja karyawan. Hasil penelitiannya secara empiris membuktikan bahwa gaya kepemimpinan berpengaruh positif pada kinerja karyawan. Penelitian dtersebut juga didukung dengan hasil penelitian yang dilakukan oleh Mohammed et al., 2014), Ghazzawi et al., (2017), dan Untari dkk., (2015) yang menunjukkan bahwa adanya pengaruh positif antara gaya kepemimpinan situasional dengan kinerja karyawan Berdasarkan hasil penelitian tersebut, maka dibangun rumusan hipotesis sebagai berikut.

$\mathrm{H}_{1}$ : Gaya kepemimpinan situasional berpengaruh positif pada kinerja karyawan di Koperasi Pasar Srinadi Klungkung.

Motivasi merupakan dorongan yang akan membuat seseorang berupaya untuk menjalankan kegiatan atau melaksanakan tugas. Seseorang yang memiliki tingkat motivasi rendah tentunya akan membuat perusahaat sulit mencapai tujuan atau bahkan merugi. Motivasi merupakan hal yang sangat penting dimiliki setiap individu dalam bekerja agar mampu menghasilkan kinerja yang optimal. Motivasi dapat bersumber dari dalam diri individu maupun dorongan dari luar seperti pemimpin dan lingkungan kerja. Bawahan akan lebih mudah digerakkan oleh pemimpin dengan adanya motivasi (Guven, 2013). Penelitian yang dilakukan oleh Elqadri et al., (2015), Zameer et al., (2014), Karma dkk., (2016) dan Husna dkk., (2016) mengenai pengaruh motivasi pada kinerja karyawan memperoleh hasil positif. Ini menunjukkan bahwa semakin tinggi motivasi yang dimiliki karyawan maka kinerja karyawan akan semakin meningkat. Berdasarkan hasil penelitian tersebut, maka dibangun rumusan hipotesis sebagai berikut. 
ISSN: 2302-8556

E-Jurnal Akuntansi Universitas Udayana

Vol.25.3.Desember (2018): 2212- 2241

$\mathrm{H}_{2}$ : Motivasi berpengaruh positif pada kinerja karyawan di Koperasi Pasar Srinadi Klungkung.

Pelatihan merupakan upaya yang dilakukan perusahaan untuk meningkatkan kinerja karyawan melalui pemberian wawasan, keterampilan dan kemampuan teknis. Pelatihan sangat berperan penting bagi kelangsungan hidup perusahaan, karena dengan adanya pelatihan, maka kualitas kerja karyawan akan semakin terjamin. Meningkatnya kualitas kerja sudah tentu akan memberikan dampak positif bagi pencapain tujuan perusahaan. Perusahaan cenderung lebih mudah merealisasikan visi, misi dan sasaran perusahaan melalui kinerja karyawan yang optimal (Bhat, 2013). Turere (2013) menyatakan bahwa pelatihan berpengaruh positif dan signifikan pada kinerja karyawan. Hasil penelitian ini diperkuat oleh hasil penelitian yang dilakukan oleh Dewi, (2014), Afroz (2018) dan Elnaga \& Imran (2013), yang secara empiris membukikan bahwa pelatihan berpengaruh positif pada kinerja pegawai. Berdasarkan hasil penelitian tersebut, maka dibangun rumusan hipotesis sebagai berikut.

$\mathrm{H}_{3}$ : Pelatihan berpengaruh positif pada kinerja karyawan di Koperasi Pasar

\section{METODE PENELITIAN}

Penelitian ini menggunakan pendekatan kuantitatif yang berbentuk asosiatif. Koperasi Pasar Srinadi Klungkung dijadikan sebagai lokasi penelitian dengan objek yang diteliti adalah kinerja karyawan.Variabel-variabel yang digunakan meliputi variabel dependen yaitu kinerja karyawan (Y) dan variabel independen yaitu gaya kepemimpinan situasional $\left(\mathrm{X}_{1}\right)$, motivasi $\left(\mathrm{X}_{2}\right)$ dan pelatihan $\left(\mathrm{X}_{3}\right)$. Jumlah populasinya sebanyak 350 karyawan yang tersebar di sembilan unit usaha dan sampel yang digunakan untuk mewakili populasi sebanyak 78 karyawan. 
Ni Luh Komang Sri Noviani dan Ni Luh Sari Widhiyani. Pengaruh...

Jumlah sampel yang digunakan diperoleh dengan menggunakan rumus Slovin yaitu: $\mathrm{N}=\mathrm{N} /\left(1+\mathrm{Ne}^{2)}\right.$ dan teknik penentuan sampel yang digunakan adalah teknik proportional random sampling, yaitu menetapkan sampel berdasarkan proporsi tertrntu.

Metode pengumpulan data yang digunakan adalah metode survei, dengan teknik kuesioner yaitu teknik pengumpulan data yang dilakuan dengan cara memberikan seperangkat pertanyaan atau pernyataan tertulis kepada responden untuk dijawabnya (Sugiyono, 2017:142). Penyebaran kuesioner dilakukan secara proporsional dengan penghitungan sebagai berikut.

$\frac{\text { Jumlah populasi setiap unit }}{\text { Jumlah seluruh populasi }} x$ Jumlah sampel

Analisis regresi linear berganda digunakan sebagai teknik analisis data dalam penelitian. Analisis data berpedoman pada hasil kuesioner yang diukur menggunakan skala likert 4 poin. Tahapan analisis terdiri dari (1) statistik deskriptif, (2) uji asumsi klasik meliputi uji normalitas, uji multikolinieritas dan uji heteroskedastisitas), (3) analisis regresi linear berganda, (4) pengujian hipotesisi meliputi uji koefisien determinasi $\left(\mathrm{R}^{2)}\right.$, uji statistik $\mathrm{F}$ (uji kelayakan model) dan uji statistik t (uji hipotesis). Analisis regresi berganda (multiple linear regression) digunakan untuk melihat pengaruh variabel gaya kepemimpinan situasional, motivasi dan pelatihan terhadap kinerja karyawan, model persamaan analisis regresi linier bergandadalam penelitian ini adalah adalah sebagai berikut.

$\mathrm{Y}=\alpha+\beta_{1} . \mathrm{X} 1+\beta_{2} . \mathrm{X} 2+\beta_{3} . \mathrm{X} 3+\mathrm{e}$

Keterangan

$\mathrm{Y} \quad=$ Kinerja karyawan

A $\quad=$ Konstanta 


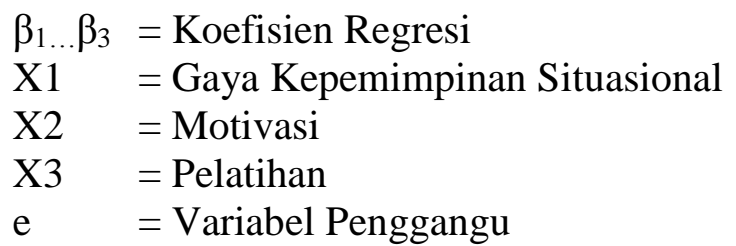

\section{HASIL DAN PEMBAHASAN}

Kuesioner yang disebar dalam penelitian ini sebanyak 78 untuk sembila unit usaha. Unit swalayan mini mendapat kuesioner paling banyak karena unit tersebut merupakan unit yang paling banyak menyerap karyawan. Unit paling sedikit mendapat kuesioner adalah unit radio yaitu sebanyak 1 eksemplar karena karyawan di unit tersebut hanya berjumlah 5 orang. Jumlah kuesioner yang disebar disesuaikan dengan metode penentuan sampel yaitu dengan menggunakan rumus Slovin dan teknik proportional random sampling. Bersadarkan hasil pengukuran Slovin dari 350 populasi penelitian, maka jumlah sampel yang digunakan untuk mewakili populasi adalah sebanyak 78 sampel yang diperoleh secara proporsional dari sembilan unit usaha.

Tabel 1.

Daftar Penyebaran Kuesioner

\begin{tabular}{clcc}
\hline No & \multicolumn{1}{c}{ Nama Unit Usaha } & Populasi & Sampel \\
\hline 1 & Unit Simpat Pinjam & 63 & 14 \\
2 & Unit Grosir & 23 & 5 \\
3 & Unit Swalayan Mini & 39 & 9 \\
4 & Unit Percetakan dan Konvekasi & 40 & 9 \\
5 & Unit Bengkel & 24 & 5 \\
6 & Unit Radio & 5 & 1 \\
7 & Unit Supermarket Inti & 65 & 15 \\
8 & Unit Bangunan & 60 & 13 \\
9 & Unit Wisata Tirta & 31 & 7 \\
& & 350 & 78 \\
\hline
\end{tabular}

Sumber: Data diolah 2018

Statistik deskriptif bertujuan untuk menganalisis data melalui cara deskripsi atau memberikan gambaran bahwa data yang terkumpul sesuai dengan 
kondisi di lapangan tanpa membuat kesimpulan umum atau generalisasi (Sugiyono, 2017:147).

Tabel 2.

Hasil Statistik Deskriptif

\begin{tabular}{cccccc}
\hline Variabel & $\mathbf{N}$ & Minimum & Maksimum & Mean & Std. Deviasi \\
\hline $\mathrm{Y}$ & 78 & 10,00 & 24,00 & 16,1538 & 4,18121 \\
$\mathrm{X}_{1}$ & 78 & 12,00 & 24,00 & 17,9478 & 3,75516 \\
$\mathrm{X}_{2}$ & 78 & 8,00 & 16,00 & 10,4359 & 2,28825 \\
$\mathrm{X}_{3}$ & 78 & 24,00 & 48,00 & 33,0897 & 6,56473 \\
Valid N (Listwis) & 78 & & & &
\end{tabular}

Nilai sebesar 10,00 menunjukkan nilai terendah dan nilai sebesar 24,00 menunjukkan nilai tertinggi dari variabel gaya kepemimpinan situasional. Nilai 16,1538 adalah nilai rata-rata dari variabel gaya kepemimpinan situasional. Hal ini menunjukkan bahwa rata-rata nilai variabel gaya kepemimpinan situasional mendekati nilai maksimum daripada nilai minimumnya. Hasil tersebut menandakan bahwa sebagian besar responden berpendapat bahwa indikator gaya kepemimpinan situasional dapat meningkatkan kinerja karyawan, sedangkan untuk nilai sebesar 4,18121 yang merupakan standar deviasi menunjukkan bahwa sebaran data dapat dikatakan baik karena tidak melebihi dua kali rata-ratanya.

Nilai sebesar 12,00 menunjukkan nilai terendah dan nilai sebesar 24,00 menunjukkan nilai tertinggi dari variabel motivasi. Nilai 17,9487 adalah nilai ratarata dari variabel motivasi. Hal ini menunjukkan bahwa rata-rata nilai variabel gaya motivasi mendekati nilai maksimum daripada nilai minimumnya. Hasil tersebut menandakan bahwa sebagian besar responden berpendapat bahwa indikator motivasi dapat meningkatkan kinerja karyawan sedangkan untuk nilai sebesar 3,75516 yang merupakan standar deviasi menunjukkan bahwa sebaran data dapat dikatakan baik karena tidak melebihi dua kali rata-ratanya. 
Nilai sebesar 8,00 menunjukkan nilai terendah dan nilai sebesar 16,00 menunjukkan nilai tertinggi dari variabel pelatihan. Nilai 10,4359 adalah nilai rata-rata dari variabel pelatihan. Hal ini menunjukkan bahwa rata-rata nilai variabel motivasi mendekati nilai maksimum daripada nilai minimumnya. Hasil tersebut menandakan bahwa sebagian besar responden berpendapat bahwa indikator pelatihan dapat meningkatkan kinerja karyawan, sedangkan untuk nilai sebesar 2,28825 yang merupakan standar deviasi menunjukkan bahwa sebaran data dapat dikatakan baik karena tidak melebihi dua kali rata-ratanya.

Nilai sebesar 24,00 menunjukkan nilai terendah dan nilai sebesar 48,00 menunjukkan nilai tertinggi dari variabel kinerja. Nilai 33,0897 adalah nilai ratarata dari variabel kinerja. Hal ini menunjukkan bahwa rata-rata nilai variabel gaya kinerja mendekati nilai maksimum daripada nilai minimumnya. Hasil tersebut menandakan bahwa sebagian besar responden berpendapat bahwa kinerja karyawan di Koperasi Pasar Srinadi adalah mengalami peningkatan, sedangkan untuk nilai sebesar 6,56473 yang merupakan standar deviasi menunjukkan bahwa sebaran data dapat dikatakan baik karena tidak melebihi dua kali rata-ratanya.

Pengujian validitas dilakukan dengan menghitung nilai Pearson Correlation. Adapun syarat minimum suatu kuesioner dinyatakan layak uji validitas apabila nilai $r$ yang dihasilkan bernilai minimal 0,3. Apabila korelasi terhadap item skor total nilainya lebih besar dari nilai $i$ kritis $(0,30)$, maka instrumen penelitian dikatakan valid. 
Tabel 3.

Hasil Uji Validitas

\begin{tabular}{|c|c|c|c|c|}
\hline No & Variabel & $\begin{array}{c}\text { Item } \\
\text { Pernyataan } \\
\end{array}$ & $\begin{array}{c}\text { Pearson } \\
\text { correlation } \\
\end{array}$ & Keterangan \\
\hline \multirow[t]{6}{*}{1} & Gaya Kepemimpinan Situasional & $\mathrm{X} 1.1$ & 0,994 & Valid \\
\hline & & $\mathrm{X} 1.2$ & 0,997 & Valid \\
\hline & & $\mathrm{X} 1.3$ & 0,994 & Valid \\
\hline & & $\mathrm{X} 1.4$ & 0,985 & Valid \\
\hline & & $\mathrm{X} 1.5$ & 0,979 & Valid \\
\hline & & X1.6 & 0,985 & Valid \\
\hline \multirow[t]{6}{*}{2} & Motivasi & $\mathrm{X} 2.1$ & 0,973 & Valid \\
\hline & & $\mathrm{X} 2.2$ & 0,956 & Valid \\
\hline & & $\mathrm{X} 2.3$ & 0,925 & Valid \\
\hline & & $\mathrm{X} 2.4$ & 0,992 & Valid \\
\hline & & $\mathrm{X} 2.5$ & 0,973 & Valid \\
\hline & & $\mathrm{X} 2.6$ & 0,957 & Valid \\
\hline \multirow[t]{4}{*}{3} & Pelatihan & X3.1 & 0,989 & Valid \\
\hline & & X3.2 & 0,981 & Valid \\
\hline & & X3.3 & 0,957 & Valid \\
\hline & & X3.4 & 0,969 & Valid \\
\hline \multirow[t]{12}{*}{4} & Kinerja Karyawan & Y.1 & 0,645 & Valid \\
\hline & & Y.2 & 0,790 & Valid \\
\hline & & Y.3 & 0,937 & Valid \\
\hline & & Y.4 & 0,938 & Valid \\
\hline & & Y.5 & 0,938 & Valid \\
\hline & & Y.6 & 0,645 & Valid \\
\hline & & Y.7 & 0,790 & Valid \\
\hline & & Y.8 & 0,937 & Valid \\
\hline & & Y.9 & 0,938 & Valid \\
\hline & & Y.10 & 0,938 & Valid \\
\hline & & Y.11 & 0,645 & Valid \\
\hline & & Y.12 & 0,790 & Valid \\
\hline
\end{tabular}

Sumber: Data diolah, 2018

Hasil uji validitas menunjukkan bahwa instrumen penelitian yang terdiri dari item-item pertanyaan gaya kepemimpinan situasional $\left(\mathrm{X}_{1}\right)$, motivasi $\left(\mathrm{X}_{2}\right)$, pelatihan $\left(\mathrm{X}_{3}\right)$, kinerja karyawan $(\mathrm{Y})$ adalah valid. Hal ini ditunjukkan dengan nilai korelasi antara skor masing - masing pertanyaan dengan skor total besarnya diatas 0,30 .

Pengujian reliabilitas digunakan untuk mengukur kuesioner yang merupakan indikator dari variabel. Pengujian ini dilakukan dengan menggunakan 
ISSN: 2302-8556

E-Jurnal Akuntansi Universitas Udayana

Vol.25.3.Desember (2018): 2212- 2241

Cronbach Alpha. Adapun kriteria pengambilan keputusan dalam uji reliabilitas yaitu koefisien Cronbach Alpha > 0,7 maka pertanyaan dinyatakan andal (Ghozali, 2016:43).

Tabel 4.

Hasil Uji Reliabilitas

\begin{tabular}{|c|c|c|}
\hline Variabel & Koefisien Alpha Cronbach & Keterangan \\
\hline Gaya Kepemimpinan Situasional & 0,994 & Reliabel \\
\hline Motivasi & 0,984 & Reliabel \\
\hline Pelatihan & 0,982 & Reliabel \\
\hline Kinerja Karyawan & 0,960 & Reliabel \\
\hline
\end{tabular}

Sumber: Data diolah, 2018

Hasil uji reliabilitas menunjukkan bahwa variabel-variabel yang digunakan dalam penelitian ini adalah reliabel. Hal ini dapat dilihat dari nilai koefisien Cronbach's Alpa dari maasing-masing variabel lebih besar dari 0,70, sehingga semua varibel layak digunakan menjadi alat ukur instrumen kuesioner dalam penelitian ini.

Pengujian normalitas bertujuan untuk menguji apakah model regresi yang menunjukkan hubungan antara variabel terikat dan variabel bebas memiliki distribusi normal atau tidak (Ghozali, 2016:154). Statistik Kolmograv-Smirnov atau K-S digunakan sebagai alat uji normalitas dalam penelitian ini. Kriteria yang digunakan dalam uji ini adalah dengan membandingkan antara tingkat signifikansi yang didapat dengan tingkat alpha yang digunakan yaitu $5 \%(0,05)$, dimana data tersebut dikatakan berdistribusi normal bila sig $\geq$ alpha. Begitu pula sebaliknya apanila nilai sig $\leq$ alpha, maka data dikatakan tidak berdistribusi normal, sehingga data yang diperoleh tidak dapat melewati proses pengujian lebih lanjut. 
Tabel 5.

Hasil Uji Normalitas

\begin{tabular}{llr}
\hline & & Unstandardized Residual \\
\hline $\mathrm{N}$ & & 78 \\
Normal Parameters $^{\mathrm{a}, \mathrm{b}}$ & Mean & 0,0000000 \\
& Std. Deviation & 3,11807953 \\
& Absolute & 0,127 \\
Most Extreme Differences & Positive & 0,127 \\
& Negative & $-0,090$ \\
Test Statistic & & 1,117 \\
Asymp. Sig. (2-tailed) & & $0,164^{\mathrm{d}}$ \\
\hline Sumber: Data diolah, 2018 & &
\end{tabular}

Nilai signifikansi dari hasil uji normalitas pada persamaan tersebut sebesar 0,164.

Hal tersebut menandakan bahwa hasil uji normalitas menunjukkan data berdistribusi normal karena nilai Asymp. Sig lebih besar dari 0,05.

Uji multikolinearitas yang dilakukan dapat dilihat dari nilai tolerance atau variance inflation factor (VIF). Apabila nilai tolerance lebih besar dari $10 \%$ atau VIF kurang dari 10, maka model regresi telah bebas dari masalah multikolinearitas

Tabel 6.

Hasil Uji Multikolinearitas

\begin{tabular}{cccccc}
\hline Model & \multicolumn{2}{c}{$\begin{array}{c}\text { Unstandardized } \\
\text { Coefficients }\end{array}$} & $\begin{array}{c}\text { Standardized } \\
\text { Coefficients }\end{array}$ & \multicolumn{2}{c}{ Collinearity Statistics } \\
\cline { 2 - 5 } & B & $\begin{array}{c}\text { Std. } \\
\text { Error }\end{array}$ & Beta & Tolerance & VIF \\
\hline (Constant) & $-9,380$ & 2,819 & & & \\
$\mathrm{X}_{1}$ & 0,935 & 0,095 & 0,596 & 0,831 & 1,204 \\
$\mathrm{X}_{2}$ & 0,840 & 0,102 & 0,481 & 0,895 & 1,117 \\
$\mathrm{X}_{3}$ & 1,117 & 0,174 & 0,410 & 0,826 & 1,210 \\
\hline
\end{tabular}

Sumber: Data diolah, 2018

Variabel bebas dalam model regresi tidak saling berkorelasi, hal ini ditunjukkan dengan nilai tolerance dari masing-masing variabel lebih besar dari 0,10 dan nilai VIF diperoleh lebih kecil dari 10. Artinya tidak adanya korelasi antara sesama variabel bebas dalam model dan model dapat dikatakan telah bebas dari masalah multikolinearitas. 
Uji Uji heteroskedastisitas dilakukan untuk menguji apakah dalam model regresi terjadi ketidaksamaan variance dari residual satu pengamatan ke pengamatan yang lain. Model regresi yang tidak terjadi heteroskedastisitas adalah bentuk model regresi yang baik. Uji Glejser digunakan untuk mendeteksi kasus heteroskedastisitas dengan melihat tingkat signifikansi berada di atas 0,05 (Ghozali, 2016:134).

Tabel 7.

Hasil Uji Heterokedastisitas

\begin{tabular}{cccccc}
\hline Model & \multicolumn{2}{l}{ Unstandardized Coefficients } & $\begin{array}{c}\text { Standardized } \\
\text { Coefficients }\end{array}$ & t & Sig. \\
\cline { 2 - 4 } & B & Std. Error & Beta & & \\
\hline (Constant) & 2,433 & 1,692 & & 1,433 & 0,155 \\
$\mathrm{X}_{1}$ & $-0,057$ & 0,057 & $-0,127$ & $-1,005$ & 0,318 \\
$\mathrm{X}_{2}$ & 0,062 & 0,061 & 0,122 & 1,004 & 0,318 \\
$\mathrm{X}_{3}$ & $-0,014$ & 0,105 & $-0,017$ & $-0,136$ & 0,892 \\
\hline
\end{tabular}

Sumber: Data diolah, 2018

Nilai signifikansi masing-masing variabel pada model regresi nilainya lebih besar dari 0,05. Hal ini menunjukkan bahwa hasil uji heteroskedastisitas terhadap model regresi tersebut tidak megandung heteroskedastisitas.

Analisis regresi linear berganda digunakan untuk untuk melihat pengaruh variabel $\mathrm{X}$ terhadap variabel $\mathrm{Y}$. Persamaan regresi linear berganda dalam penelitian ini adalah sebagai berikut:

$\mathrm{Y}=-9380+0,935 \mathrm{X}_{1}+0,840 \mathrm{X}_{2}+1,177 \mathrm{X}_{3}+\mathrm{e}$

Tabel 8.

Hasil Analisis Regresi Linear Berganda

\begin{tabular}{cccccc}
\hline Model & \multicolumn{2}{c}{ Unstandardized Coefficients } & $\begin{array}{c}\text { Standardized } \\
\text { Coefficients }\end{array}$ & T & Sig. \\
\cline { 2 - 4 } & $\mathbf{B}$ & Std. Error & Beta & & \\
\hline (Constant) & $-9,380$ & 2,819 & & $-3,327$ & 0,001 \\
X $_{1}$ & 0,935 & 0,095 & 0,596 & 9,833 & 0,000 \\
X $_{2}$ & 0,840 & 0,102 & 0,481 & 8,237 & 0,000 \\
X $_{3}$ & 1,117 & 0,174 & 0,410 & 6,752 & 0,000 \\
Adjusted R Square & & 0,765 & & \\
\multicolumn{2}{c}{ Sig. F } & & 0,000 & & \\
\hline
\end{tabular}

Sumber: Data diolah, 2018 
Nilai koefisien beta dari variabel gaya kepemimpinan situasioal bernilai positif ini berarti semakin tinggi gaya kepemimpinan situasional, menyebabkan kinerja karyawan semakin meningkat. Nilai koefisien beta dari variabel motivasi bernilai positif ini berarti semakin tinggi motivasi, maka kinerja karyawan akan semakin meningkat. Nilai koefisien beta dari variabel pelatihan bernilai positif ini berarti semakin tinggi pelatihan, maka kinerja karyawan akan semakin meningka. Nilai konstanta sebesar -9,380 menunjukkan bahwa variabel gaya kepemimpinan situasional, motivasi, pelatihan sama dengan nol (tetap atau tidak berubah), menyebabkan kinerja karyawan akan menurun sebesar nilai konstantanya.

Koefisien beta standardized dari variabel gaya kepemimpinan situasional memiliki nilai yang paling tinggi yaitu sebesar 0,596, sedangkan variabel motivasi sebesar 0,481 dan yang paling kecil nilai koefisien beta standardized adalah pelatihan sebesar 0,410 . Hal ini menujukan bahwa variabel gaya kepemimpinan situasional merupakan variabel yang paling berpengaruh terhadap kinerja karyawan. Nilai Adjusted Rsquare sebesar 0,765, nilai tersebut menunjukkan bahwa $76,5 \%$ perubahan yang terjadi pada kinerja karyawan dijelaskan oleh gaya kepemimpinan situasional, motivasi dan pelatihan, sedangkan sisanya sebesar 23,5 persen dijelaskan oleh faktor lain yang tidak diuji dalam penelitian ini. Nilai signifikansi $\mathrm{F}$ atau $p$-value sebesar 0,000 yang lebih kecil dari nilai $\alpha=0,05$. Artinya regresi ini layak digunakan sebagai alat analisis untuk menguji pengaruh variabel bebas pada variabel terikat.

Hipotesis pertama $\left(\mathrm{H}_{1}\right)$ dalam penelitian ini diterima karena nilai koefisien regresi variabel gaya kepemimpinan situasional sebesar 0,935 dengan tingkat 
signifikansi sebesar $0,000<0,05$. Artinnya gaya kepemimpinan situasional memiliki pengaruh positif dan siginifikansi pada kinerja karyawan. Hipotesis kedua $\left(\mathrm{H}_{2}\right)$ dalam penelitian diterima karena nilai koefisien regresi variabel motivasi sebesar 0,840 dengan tingkat signifikansi adalah $0,000<0,05$. Artinya motivasi berpengaruh positif dan signifikan pada kinerja karyawan. Hipotesis ketiga $\left(\mathrm{H}_{3}\right)$ dalam penelitian ini diterima karena nilai koefisien regresesi variabel pelatihan sebesar 1,177 dengan tingkat signifikansi adalah $0,000<0,05$. Artinya pelatihan berpengaruh positif dan signifikan pada kinerja karyawan.

Pengujian terhadap variabel gaya kepemimpinan situasional memperlihatkan hubungan positif dan signifikan antara gaya kepemimpinan situasional dengan kinerja karyawan. Hal ini menunjukkan bahwa meningkatnya kepemimpinan situasional akan meningkatkan kinerja pegawai. Adapun gaya kepemimpina situasional yang diterapkan oleh manajer umum Koppas Srinadi Klungkung dapat dilihat dari perilaku hubungan, perilaku tugas dan kematangan bawahan yang diterapkan selama mengelola koperasi.

Hasil pengujian variabel motivasi menunjukkan bahwa motivasi memiliki hubungan positif dan signifikan dengn kinerja karyawan. Hal tersebut mengindikasikan bahwa motivasi yang tinggi akan berimbas pada kinerja karyawan yang semakin tinggi pula. Pengujian terhadap variabel motivasi menunjukkan bahwa motivasi telah diberikan oleh manajer umum koperasi kepada karyawan. Motivasi yang diberikan oleh manajer umum Koppas Srinadi Klungkung berupa motifasi berafiliasi, motivasi berkuasa dan motivasi berprestasi. Motivasi yang bersumber dari manajer merupakan salah satu bentuk 
motivasi yang berasal dari faktor ekternal dan motivasi dari dalam diri karyawan merupakan motivasi yang berasal dari faktor internal.

Hasil pengujian pelatihan menunjukkan bahwa terdapat hubungan positif dan signifikan antara pelatihan dengan kinerja karyawan. Hubungan positif yang diperoleh dari hasil pengujian mengindikasikan bahwa pemberian pelatihan akan memacu karyawan untuk meningkatkan kinerja. Ini berarti manajer Koppas Srinadi Klungkung telah memberikan pelatihan pada karyawan dan hasil pelatihan yang diberikan sangat membantu dalam meningkatkan kinerja karyawan. Pemberian pelatihan akan membantu menambah wawasan dan keterampilan karyawan, sehingga kemampuan teknis karyawan dalam menjalankan tugas akan semakin membaik. Selain intensitas pelatihan, materi yang tepat pada saat pemberian pelatihan juga sangat penting dalam meningkatkan kinerja karyawan.

\section{SIMPULAN}

Gaya kepemimpinan situasional, motivasi dan pelatihan memiliki pengaruh positif dan signifikan pada kinerja karyawan. Hal ini menandakan bahwa semakin tinggi gaya kepemimpinan situasional, motivasi dan pelatihan yang diberikan pada karyawan maka kinerja karyawan akan mengalami peningkatan. Manajer umum Kopersi Pasar Srinadi Klungkung harus mengadakan pelatihan secara menyeluruh kepada semua karyawan baik yang berstatus karyawan baru maupun karyawan lama. Seluruh karyawan Kopersi Pasar Srinadi Klungkung juga harus secara serentak meningkatkan pelayanan kepada anggota maupun masyarakat serta selalu mengedepankan cara-cara baru dalam memecahkan permasalahn yang ada di koperasi, sehingga kinerja koperasi akan semakin membaik. 


\section{REFERENSI}

Afroz, N. N. (2018). Effects of Training on Employee Performance - A Study on Banking Sector, Tangail Bangladesh. Global Jurnal of Economics and Business, 4(1), 111-124.

Afshinpour, S., Germain, M., Tomlin, M. E., \& Anderson, T. (2013). The Role of Situational Leadership Style in Employee Satisfaction in an Iranian Oil Company. Organization Resouces Mnagement Research, 3(3), 136-151.

Amalia, D. R., Swasto, B., \& Susilo, H. (2016). Pengaruh Gaya Kepemimpinan terhadap Motivasi Kerja dan Kinerja Karyawan (Studi pada Karyawan Pabrik Gula Kebon Agung Malang ). Jurnal Administrasi Bisnis (JAB), Universitas Brawijaya, 36(1), 137-146.

Bhargavi, S., \& Yaseen, A. (2016). Leadership Styles and Organizational Performance. Strategic Management Quarterly, 4(1), 87-117. https://doi.org/10.15640/smq.v4n1a5

Bhat, Z. H. (2013). Impact of Training on Employee Performance: A Study of Retail Banking Sector in India. Indian Journal of Applied Research, 3(6), 292-293. https://doi.org/10.15373/2249555X/JUNE2013/97

Cote, R. (2017). A Comparison of Leadership Theories in an Organizational Environment. International Journal of Business Administration, 8(5), 28-35. https://doi.org/10.5430/ijba.v8n5p28

Dewi, S. K. P. (2014). Pengaruh Pelatihan, Motivasi Kerja dan Lingkungan Kerja terhadap Kinerja Karyawan Koperasi Mahasiswa (KOPMA) di Kabupaten Sleman. Jurnal Bisnis Dan Ekonomi, Universitas Janabadra, 5(1), 48-72.

Duquesnoy, P. (2011). Generations, Leadership Style and Employee Performance. School of Social and Behavioral Sciences, Tilburg University, 2-46. Retrieved from http://arno.uvt.nl/show.cgi?fid=115021

Elnaga, A., \& Imran, A. (2013). The Effect of Training on Employee Performance. European Jurnal of Business and Management, 5(4), 137-147.

Elqadri, Z. M., Priyono, P., Suci, R. P., \& Chandra, T. (2015). Effect of Leadership Style, Motivation, and Giving Incentives on the Performance of Employees-PT. Kurnia Wijaya Various Industries. International Education Studies, 8(10), 183-192. https://doi.org/10.5539/ies.v8n10p183

Gardjito, A. H., Musadieq, M. Al, \& Nurtjahjono, G. E. (2014). Pengaruh Motivasi Kerja dan Lingkungan Kerja terhadap Kinerja Karyawan (Studi 
pada Karyawan Bagian produksi PT.Karmand Mitra Andalan Surabaya. Jurnal Administrasi Bisnis (JAB), Universitas Brawijaya, 13(1).

Ghazzawi, K., Shoughari, R. El, \& Osta, B. El. (2017). Situational Leadership and Its Effectiveness in Rising Employee Productivity: A Study on North Lebanon Organization. Human Resource Management Research, 7(3), 102110. https://doi.org/10.5923/j.hrmr.20170703.02

Guven, G. O. (2013). Challenges in Achieving High Motivation and Performance in Educational Management: Case Study of a North Cyprus Public High School. International Journal of Humanities and Social Science, 3(6), 20-26.

Hidayati, S., Utami, H. U., \& Prasetya, A. (2015). Pengaruh Gaya Kepemimpinan Situasional terhadap Kepuasan Kerja dan Kinerja Karyawan (Studi pada Karyawan Divisi Tower \& Approach Terminal (TWR\&APP-TMA) AirNav Indonesia Kantor Cabang Aero Traffic Control Soekarno Hatta). Jurnal Administrasi Bisnis (JAB), Universitas Brawijaya, 26(2), 1-9.

Husna, D. A., Sunuharjo, B. S., \& Djudi, M. (2016). Pengaruh Motivasi Kerja dan Kemampuan Kerja terhadap Kinerja Karyawan (Studi pada Karyawan PT. PLN (Persero) Distribusi Jawa Timur Area Malang). Jurnal Administrasi Bisnis (JAB), Universitas Brawijaya, 36(1), 153-162.

Iqbal, N., Anwar, S., \& Haider, N. (2015). Effect of Ledearship Style on Employee Performance. Arabian Journal of Business and Management Review, 5(5), 1-6. https://doi.org/10.4172/2223-5833.1000146

Karma, K. F. A., Yasa, G. W., \& Ratnadi, N. M. D. (2016). Pengaruh Gaya Kepemimpinan Situasional, Budaya Organisasi dan Motivasi pada Kinerja Karyawan di PT Bnak Pembangunan Daerah Bali Cabang Badung. E-Jurnal Ekonomi Dan Bisnis, Universitas Udayana, 5(11), 3823-3856.

Kementerian Koperasi dan UMKM Republik Indonesia. (2018). http://nik.depkop.go.id/. Diakses 1 Maret 2018.

Kontan.co.id- Jakarta. 2017.13 Koperasi Unggulan Indonesia_http://www.diskopukm.baliprov.go.id/id/-Bali--KompetitorKoperasi-Terbaik. Diakses 1 Maret 2018

Kusuma, G. C., Musadieq, M. Al, Nurtjahjono, G. E., Administrasi, F. I., \& Brawijaya, U. (2015). Pengaruh Motivasi dan Pelatihan terhadap Kinerja (Studi pada Karyawan PT. PLN (Persero) Distribusi Jawa Timur Area Malang. Jurnal Administrasi Bisnis (JAB), Universitas Brawijaya, 21(1), 17. 
Mohammed, U. D., Yusuf, M. O., Sanni, I. M., Ifeyinwa, T. N., Bature, N. U., \& Kazeem, A. O. (2014). The Relationship between Leadership Styles and Employees' Performance in Organizations (A Study of Selected Business Organizations in Federal Capital Territory, Abuja Nigeria). European Journal of Business and ManagementOnline), 6(22), 1-11.

Mulyadi, D. 2015. Perilaku Organisasidan Kepemimpinan Pelayanan. Cetakan Pertama Bandung: Penerbit Alfabeta.

Putera, Sukadana. 2018. Suwirta Undercover. Klungkung: PT. Japa Widya Duta.

Purnamasari, H. (2016). Administrasi Kependudukan (Studi Pelayanan Pembuatan Kartu Keluarga (KK) pada Kantor Kecamatan Lemahabang Kabupaten Karawang ). Jurnal Politikom Indonesiana, 1(1), 154-163.

Ramya. (2016). The Effect of Training on Employe Performance. International Journal of Scientific Research and Modern Education (IJSRME), I(I), 697706.

Riani, M. E., Maarif, M. S., \& Affandi, J. (2017). Pengaruh Program Pelatihan dan Motivasi Kerja terhadap Kinerja Karyawan PT. Td Automotive Compressor Indonesia. Jurnal Aplikasi Bisnis Dan Manajemen, 3(2), 290298. https://doi.org/10.17358/jabm.3.2.290

Samsuri, Margono, A., \& Sugandi. (2014). Pengaruh Gaya Kepemimpinan Situasional dan Disiplin Kerja terhadap Prestasi Kerja Pegawai pada Sekretariat Daerah Kabupaten Kutai Timur. E-Journal Administrative Reform, 2(1), 1076-1089.

Subekhi, Ahmad., dan Jauhar, M. 2013. Pengantar Teori dan Perilaku Organisasi. Cetakan Pertama, Jakarta: Penerbit Prestasi Pustaka.

Sudarmanto. 2009. Kinerja dan Pengembangan Kompetensi SDM . Yogyakarta: Pustaka Pelajar.

Suprihanto J., dkk., 2003. Perilaku organisasional. Yogyakarta: Sekolah Tinggi Ilmu Ekonomi YKPN.

Thoha, Miftah. 2007. Perilaku Organisasi Konsep Dasar dan Aplikasinya. Jakarta : PT.Rajagrafindo Persada.

Triayong, E. B., Hardiyanto, W. T., Aminulloh, A., Studi, P., Administrasi, I., \& Tunggadewi, U. T. (2013). Pengaruh Motivasi Kerja dan Efektivitas Kepemimpinan Camat terhadap Kinerja Pegawai. Jurnal Ilmu Sosial Dan Ilmu Politik (JISIP), Universitas Tribhuwana Tunggadewi, 2(2), 4-14. 
Turere, V. N. (2013). Pengaruh Pendidikan dan Pelatihan terhadap Peningkatan Kinerja Karyawan pada Balai Pelatihan Teknis Pertanian Kalasey. Emba, Universitas Sam Ratulangi Manado, 1(3), 10-19.

Undang-Undang Nomor 25 Tahun 1992 tentang Perkoperasian.

Untari, R. D., Boedijono, \& Azhar, A. K. (2015). Pengaruh Gaya Kepemimpinan Situasional terhadap Kinerja Aparatur Desa di Desa Tamansari Kecamatan Wuluhan Kabupaten Jember. E-Jurnal Ilmu Administrasi Negara Universitas Jember, 1(1), 1-15.

Wanjala, M. N. (2014). The Influence of Leadership Style on Employees' Job Performance in the Hospitality Industry: Case Study of Safari Park Hotel. United States International University.

Zameer, H., Ali, S., \& Amir, M. (2014). The Impact of the Motivation on the Employee' s Perfor mance in Beverage Industry of Pakistan. International Journal of Academic Research in Accounting , Finance and Management Sciences, 4(1), 293-298. https://doi.org/10.6007/IJARAFMS/v4-i1/630 